\title{
Effectiveness Of Mindfulness Based Stress Reduction On Depression In Elderly: A Systematic Review
}

\author{
Linlin Lindayani*, Agus Hendra, Lia Juniarni, Gina Nurdina \\ STIK PPNI West Java, Indonesia \\ Corresponding author: linlinlindayani@gmail.com
}

\begin{abstract}
Background: The elderly are individuals who have entered the age of 60 years (Hurlock, 2004). One of the most common elderly problems that is more commonly found is depression. Currently increasing research and reviews support the efficiency of psychotherapy treatments for depression. Based on traditional interventions Mindfulness Based Stress Reduction (MBSR) therapy is recommended for geriatric depression. MBSR therapy focuses on is one type of mindfulness-based therapy that focuses on training awareness through meditation techniques. By practicing observing body sensations (body scan meditation), individuals can achieve a mindful condition in their daily lives, including when carrying out routine activities such as walking, eating, standing. MBSR aims to change individual relationships with stressful situations and thoughts. This is achieved by decreasing emotional reactions and increasing.
\end{abstract}

Purpose: This study aimed to determine the effectiveness of MBSR therapy on the level of depression in the elderly.

Methods: Literature searches conducted through Google Scholar and PubMed studies published in English, there were 778 articles obtained but only 5 journals met the search criteria.

Results: The results of this review show that MBSR therapy has an influence to reduce the level of depression in the elderly and MBSR therapy has no side effects compared to pharmacological therapy.

Conclusion: It is hoped that health workers can implement MBSR therapy to reduce the level of depression in the elderly.

Keywords: Mindfulness Based Stress Reduction Therapy, Depression, Elderly. 
Journal Of Nursing Practice

http://thejnp.org

ISSN: 2614-3488 (print); 2614-3496 (online)

Vol.4 No.1. October 2020. Page.8-12

\section{BACKGROUND}

The elderly are individuals who have entered the age of 60 years (Hurlock, 2004). Entering a happy old age is identified with readiness to accept all changes in aspects of life (Indriana, Destiningrum, \& Kristiana, 2011). The elderly are also a group that must be considered because the numbers are quite large and will continue to increase throughout the year. Based on data from the World Population Prospects (2015), in 2015 there were 901 million people aged 60 years consisting of $12 \%$ of the total global population. Meanwhile, according to Susenas data (National Socio-Economic Survey) in 2019, the number of elderly people in Indonesia reached 29 million people, equivalent to $11 \%$ of the total population of Indonesia in 2019. Increasing the number of elderly people has changed health problems and social maps due to decreased productivity of the elderly towards body organs such as cell damage in the aging process, so that the impact on the production of enzymes, hormones, and substances that the body needs for immunity is reduced (Maryam, 2011). Elderly experiencing various problems in health, especially those related to the aging process including: hypertension, cancer, mental disorders, and man made disease (degenerative diseases) are increasing (Ministry of Health Republic of Indonesia, 2017).

The erikson development stage states that the elderly are in a phase of integrity, but if this development is not achieved there will be a problem of despair. Psychological integrity phase is a phase when an individual conducts a life review and evaluates it which reflects on a person's life experience, and interprets life changes (Santrock, 2013). These life changes include retirement, partner death, the need to care for a partner, and physical illness or disability (Nevid, Rathus \& Greene, 2005). High stressors and unpleasant life events cause mental and psychological problems in the elderly such as short term memory (memory loss), frustration, anxiety, loneliness, to depression (Hawari, 2011). according to the World Health Organization (WHO, 2017), the prevalence of depression in the elderly is around 12$36 \%$ of the elderly undergoing outpatient care due to depression. This figure increases to 30$50 \%$ in the elderly with chronic illness and long-standing care who are depressed (Azizah, 2011). The prevalence in Indonesia is based on the Information Center for NonCommunicable Diseases, the elderly who experience depression by 11.6 \& (Kemekes, 2017). The discovery of Syukra (2012), in accordance with the phenomenon of empty copulation (empety nest) that is usually experienced by the elderly, is a crisis in oneself caused by the sense of loss of children who have lived independently, entering retirement, menopause, and the death of a partner $(\mathrm{Lu}, 2010)$. Some of the major conflicts experienced by the elderly are the relinquishment of their position and authority, as well as an assessment of the abilities, successes, and satisfaction obtained previously (post power syndrome). This can have an impact on decreasing the physical and psychological condition of the elderly (Hawari, 2007).

Psychological well-being, according to Ryff and Keyes (1995), is the full achievement of one's psychological potential and a state when individuals can accept the strengths and weaknesses of what they are, have a purpose in life, develop positive relationships, become an independent person, be able to control the environment and continue to grow personally. Newman (2006) states that psychological well-being also depends on the ability to regulate or continue to be involved in valuable roles and activities. There are many ways to improve psychological well-being, namely by providing social support (Destiningrum, 2014), classical music therapy (Jasmarizal, Literature \& Yunita, 2011), elderly group psychotherapy (Zulfiana, 2014), elderly exercise (Pratiwi, 2013), and mindfulness therapy (Kinasih \& Sukma, 2010). 


\section{Journal Of Nursing Practice}

http://thejnp.org

ISSN: 2614-3488 (print); 2614-3496 (online)

Vol.4 No.1. October 2020. Page.8-12

Mindfulness is an awareness that arises as a result of giving attention to a current experience intentionally and without judgment in order to be able to respond by accepting the experiences experienced everyday (Kabat-Zinn, 2003). Mindfulness is the nature of attention and full awareness that is stable and consistent in self that encourages individuals to continue to act (Teasdale, 2002). Mindfulness is rooted in Buddhist philosophy and is a form of skill that can help individuals to have awareness and not react to what is happening now, a way to interpret events that are positive, negative, or neutral so that they are able to overcome feelings of depression and generate self-prosperity (Germer, Siegel, and Fulton, 2005). According to its operational definition, mindfulness is the capacity for: (a) observing: the ability to observe and realize the presence of thoughts, feelings, perceptions, and sensations, (b) describing: describing with words, (c) acting with awareness: acting with awareness , (d) nonreactivity: being non-reactive to personal experiences, and (e) nonjudge: behaving without an assessment of personal experiences (Roeser et al, 2012).

Mindfulness Based Stress Reduction (MBSR) is a type of mindfulness-based therapy that focuses on training awareness through meditation techniques. By practicing observing body sensations (body scan meditation), individuals can achieve a mindful condition in their daily lives, including when carrying out routine activities such as walking, eating, standing, etc. (Germer, Siegel, and Fulton, 2005). MBSR aims to change individual relationships with stressful situations and thoughts. This is achieved by decreasing emotional reactions and increasing cognitive assessment positively.

Various studies show the benefits of mindfulness programs, according to research (Gercia-Banda \& Martin-Asuero, 2010), can reduce stress, research (Davis \& Hayes, 2011), can increase attention and concentration, research (Chen, Yang, Wang, \& Zhang, 2013), can reduce anxiety and stabilize blood pressure, research (Fortney, et al, 2013), can increase job satisfaction, research (Bazarko, et al, 2013), can improve the quality of health, and according to research (White, 2013 ), can improve the quality of therapeutic services to patients.

Mindfulness therapy trains individuals not to make automatic assessments of the events being experienced. Automatic assessment will make individuals not make an objective assessment, so that coping is often done inappropriately and results in coping being ineffective (Corhorn \& Millicic, 2016). Mindfulness interventions can facilitate individuals to learn to deal with each experience more openly and without judgment. The mindfulness method uses a series of exercises designed to train the mind to remain focused and open to everyday conditions including stressful conditions (Chielsa \& Malinowski, 2011). White (2013) states that the mindfulness program for nurses can be useful as self-care and the development and improvement of their well-being. The concept of mindfulness starts from releasing the suffering experienced by humans. Suffering can include stress, depression, anxiety, interpersonal conflict, confusion, excessive worry and irrational fears (Mace, 2008). Mindfulness is believed to reduce suffering and promote well-being (Grossman \& Van Dam, 2011).

Elderly who are not psychologically prosperous tend to have more complaints about disease disorders (Khotimah, 2011). If the elderly are psychologically prosperous, this will ease the family in taking care of the elderly. Everyone will enter old age, so attention to welfare becomes essential. The importance of mindfulness-based stress reduction therapy programs on psychological well-being in the elderly with depression is important to study. So the purpose of this research is to conduct a systematic review of the effectiveness of Mindfulness Based Stress Reduction on the level of depression in the elderly. 


\section{Journal Of Nursing Practice}

http://thejnp.org

ISSN: 2614-3488 (print); 2614-3496 (online)

Vol.4 No.1. October 2020. Page.8-12

\section{METHODS}

This research is a systematic review of the existing literature to evaluate subjective responses after the application of mindfulness-based stress reduction (MBSR) therapy to psychological well-being in the elderly with depression.

\section{Search Strategy}

The search strategy aims to find articles that have been published. Data from this review literature was obtained through an online search process. The search is done through Google Scholar and PubMed. The keywords used are a combination of older or eldery and mindfulness or mind-fulness and depression. The search focused on journals using mindfulness-based stress reduction (MBSR) therapy on psychological well-being in the elderly with depression published until May 21, 2019.

The research included in this review is based on inclusion criteria: English and Indonesian, published from 2015 to 2020, human participant, clinical trial, and research searches conducted in elderly patients who are depressed.

\section{Screening Article}

Article screening is carried out through the initial title and then abstract screening is carried out to identify which articles have the potential to meet the desired criteria. After that a review of all articles considered significant at initial screening was conducted. Additional articles not found in the initial literature search were obtained by reviewing the references in the study. Two reviewers reviewed each abstract based on inclusion criteria. The first reviewer checks all the titles and abstracts the aim is to avoid repeating the article. Separately, the second reviewer rated the title and abstract samples according to the same criteria to be chosen. Furthermore, the two reviewers agreed on which articles met the inclusion criteria.

\section{Data Extraction}

Each article is processed data by making a summary of each article which includes, author, year, country of origin of the study, type of study, sample (including the number of samples and inclusion criteria), interventions, results, and research limitations.

\section{Study Quality Study}

Assessment of the quality of each article is carried out using the standard format of The Critical Appraisals Skill Program (CASP), which is already in Indonesian. The criteria used to evaluate whether each study is of good quality and a minimum risk of bias consists of 3, namely whether the results of the study are valid, what are the results, will the research results help locally. There are a total of 11 checklist items that are used to do the assessment with answer choices yes / not reported.

\section{RESULT}

From the results of searches conducted through Google Scholar and PubMed. A total of journals were obtained using a combination of older keywords. Then as many as 778 journals were obtained using a combination of keywords eldery and mindfulness, and as many as 157 journals were obtained using a combination of the keywords mindfulness and depression. So that a total of only 5 articles met all search criteria (Figure 1). 


\section{Journal Of Nursing Practice}

http://thejnp.org

ISSN: 2614-3488 (print); 2614-3496 (online)

Vol.4 No.1. October 2020. Page.8-12

Search electronics at PubMed and

Google Schoolar $(n=778)$

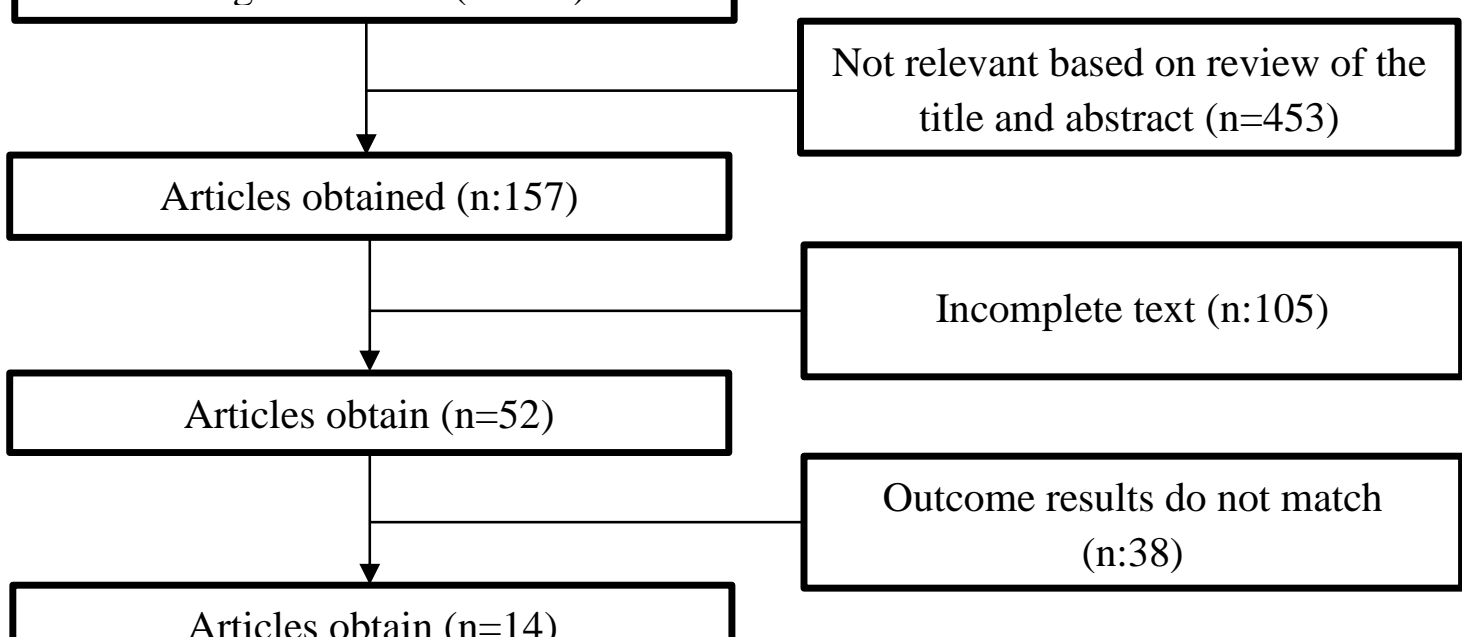

Included in the Inclusion Criteria $(\mathrm{n}=5)$

Figure 1. Diagram Flow 


\section{Table 1. Summary of included studies}

\begin{tabular}{|c|c|c|c|c|}
\hline Author / Year & Sample & Design & Results & $\begin{array}{l}\text { CASP } \\
\text { score }\end{array}$ \\
\hline $\begin{array}{l}\text { Piyanee et al } \\
(2019)\end{array}$ & $\begin{array}{l}\text { Elderly aged } 60-85 \text { years who live in the } \\
\text { community, and meet Petersen's } \\
\text { operational criteria for mild cognitive } \\
\text { impairment }\end{array}$ & $\begin{array}{l}\text { Randomize } \\
\text { d Control }\end{array}$ & $\begin{array}{l}\text { The results from one-way ANCOVA showed significant } \\
\text { differences between the MAP and HEP groups in depression }(\mathrm{F}= \\
7.88, \mathrm{p}<0.001) \text {, controlling for depression scores at baseline. }\end{array}$ & 10 \\
\hline $\begin{array}{l}\text { Maja et al } \\
(2015)\end{array}$ & $\begin{array}{l}\text { It consists of } 36 \text { participants with an } \\
\text { average age of } 65-80 \text {. Participants with } \\
\text { difficulties related to long-term mourning }\end{array}$ & $\begin{array}{l}\text { Randomize } \\
\text { d Control }\end{array}$ & $\begin{array}{l}\text { The results of this study are }(\text { Hedges' }=0.88, p=0.09) \text { there are } \\
29 \% \text { who have improved symptoms of depression both with } \\
\text { ANOVA statistical methods. }\end{array}$ & 10 \\
\hline $\begin{array}{l}\text { Autumn et al } \\
\text { (2015) }\end{array}$ & $\begin{array}{l}\text { Consisting of } 200 \text { participants aged } 65-> \\
70 \text { years who did not experience } \\
\text { congnative disorders }\end{array}$ & $\begin{array}{l}\text { Randomize } \\
\text { d Control }\end{array}$ & $\begin{array}{l}\text { Anova test shows the results of the assessment assessment } \\
\text { showed a significant group time for the PSQI global score }(p= \\
0.006) \text {; the MBSR group experienced a decrease in the global } \\
\text { PSQI score }(p=1.12) \text {. }\end{array}$ & 10 \\
\hline $\begin{array}{l}\text { Jia-xu Zhang et } \\
\text { al (2015) }\end{array}$ & $\begin{array}{l}\text { Participants consisted of } 60 \text { people with } \\
\text { inclusion criteria: } \\
\text { 1. Age> } 75 \text { years } \\
\text { 2. Minimum duration of insomnia is } 6 \\
\text { months (chronic insomnia) } \\
\text { 3. Complaints of dysfunction during the } \\
\text { day }\end{array}$ & $\begin{array}{l}\text { A } \\
\text { randomized. } \\
\text { Controlled, } \\
\text { single blind } \\
\text { clinical trial }\end{array}$ & $\begin{array}{l}\text { There was a significant time group interaction for the PSQI } \\
\text { global score }(P=.006) \text {. The MBSR group had a decrease in the } \\
\text { PSQI global score }(\text { Cohen } \mathrm{d}=1.12) \text { while the control group did } \\
\text { not (Cohen } \mathrm{d}=-0.06) \text {. }\end{array}$ & 10 \\
\hline $\begin{array}{l}\text { Petra et al } \\
(2016)\end{array}$ & $\begin{array}{l}\text { Consists of } 55 \text { participants aged 52-81 } \\
\text { years with exclusion criteria including } \\
\text { previous heart attacks, heart surgeries, } \\
\text { neurological diseases (for example: } \\
\text { stroke, marbus parkinson), severe } \\
\text { orthopedic disease, dementia or } \\
\text { psychiatric disorders. }\end{array}$ & $\begin{array}{l}\text { Randomize } \\
\text { d Control }\end{array}$ & $\begin{array}{l}\text { The results showed that there was a significant main effect of } \\
\text { time regarding SF- } 12 \text { mental summary scores }(\mathrm{p}=0.27), \mathrm{n} 2= \\
.10) \text { indicating that perceived mental health improved } \\
\text { significantly from preassessment to post assessment. However, } \\
\text { there was also a significant interaction effect of Group Time }(\mathrm{p}= \\
.05, \mathrm{n} 2=.12) \text {. }\end{array}$ & 10 \\
\hline
\end{tabular}




\section{Journal Of Nursing Practice}

http://thejnp.org

ISSN: 2614-3488 (print); 2614-3496 (online)

Vol.4 No.1. October 2020. Page.8-12

\section{Summary of research results}

Based on the above table, according to research conducted by Piyanee KlaininYobas, et al (2019), with the title The Effect of Mindfulness and Health Education Program on the Emotional State and Cognitive Function of Elderly Individuals with Mild Cognitive Impairment which aims to determine the effectiveness of mindfulness practices on the emotional state and cognitive function of the elderly who live with people with mild cognitive impairment. This type of research is an experimental study, the number of respondents 55 patients were randomized into 2 groups, the experimental group (MAP) (n $=28)$ and the control group (HEP) $(n=27)$. Obtaining results In the MAP group, the average score for depression and anxiety showed a downward trend at 2 (three months) and 3 (Nine months) compared with time 1 (baseline). Likewise, a downward trend in depression and anxiety was found in the HEP group. Cognitive function (measured by MMSE and CDR) varies slightly between times for both groups. However, all ways are below the conventional cutoff value $(<0.5)$ for dementia.

The results from one-way ANCOVA showed significant differences between the MAP and HEP groups in depression $(\mathrm{F}=7.88, \mathrm{p}<0.001)$, controlling for depression scores at baseline. Note that the MAP group had a depression score at baseline. However, the increase in depression scores was greater than the MAP group at three months (mean difference $=1.72, \mathrm{p}<0.001$ ). The difference was not statistically significant at nine months (mean difference $=1.15, \mathrm{p}=0.05$ ).

According to research conducted by Maja O Connor, Jacob Piet, Esben Hougaard, et al, in 2015, with the title The Effects of Mindfulness Based Cognitive Therapy on Depressive Symptoms in Elderly Vibrated People with Loss-Related Distress Aiming to investigate the potential effectiveness of MBCT for parents with long-term difficulties associated with mourning, several years after the death of their partner. This type of research is an experimental study, the number of respondents consists of 36 participants with an average age of 65-80 years. Participants with distress related to long-term mourning. The results obtained from the results of the study showed a significant decrease. In the control group the average score (Hedges'g $=0.84, \mathrm{p}=0.04$ ) and after 4 weeks it became (Hedges'g $=0.88, \mathrm{p}=0.02)$. in the intervention group (Hedges' $\mathrm{g}=0.84, \mathrm{p}=0.04)$ and after 4 weeks it became (Hedges'g $=0.35, \mathrm{p}=0.09$ ).

According to the research of Autumn M. galleos et al (2015), titled Emotional Benefits of Mindfulness based on stress reduction in older adults: The Moderating Roles of Age and Depressive Symptom Severity which aims to see the effects of age and severity of depressive symptoms in the elderly. This type of research is an experimental study, the number of respondents consisted of 200 participants aged $65 \rightarrow 70$ years who did not experience congnative disorders. Anova test showed the assessment assessment results showed a significant time group for the PSQI global score $(p=0.006)$; the MBSR group experienced a decrease in the global PSQI score $(\mathrm{p}=1.12)$.

According to research Ja-xu Zhang, et al (2015), with the title Mindfulness Based Stress Reduction for Chronic Insomnia in Adults Older Than 75 Years aimed at seeing a mindfulness program can be a useful treatment for reducing the level of depression in adults aged 75 years and over. This type of research is an experimental study. Participants consisted of 60 people with inclusion criteria: Age $>75$ years, duration of insomnia at least 6 months (chronic insomnia). Showing significant time group interaction results for the PSQI global score $(\mathrm{P}=.006)$ the MBSR group had a decrease in the PSQI global score (Cohen $\mathrm{d}=1.12)$ while the control group did not (Cohen $\mathrm{d}=-0.06)$. Among the PSQI components, there was a significant time $\mathrm{x}$ group interaction for daytime dysfunction $(\mathrm{P}=.048)$ Cohen from the MBSR group was 0.76 . whereas Cohen's d from the control group is -0.04 . There was no 


\section{Journal Of Nursing Practice}

http://thejnp.org

ISSN: 2614-3488 (print); 2614-3496 (online)

Vol.4 No.1. October 2020. Page.8-12

significant time $\mathrm{x}$ group interaction for SAS scores $(\mathrm{P}=.116)$, whereas for GDS there was a significant time $x$ group interaction $(\mathrm{P}=.039)$, Cohen rated for the MBSR group was 1.20 and 0.12 for the control group.

According to research by Petra Jansen, et al (2016), with the title Minfulness Training on Emotional Well Being and Cognitive Performance in Leter Life which aims to compare the effects of karate and MBRS training on emotional well-being, subjective health and cognitive performance. This type of research is an experimental study. Participants consisted of 55 participants aged 52-81 years with exclusion criteria including previous heart attacks, heart surgeries, neurological diseases (for example: stroke, marbus parkinson), severe orthopedic disease, dementia or psychiatric disorders. Obtaining results In the MBSR group, there was a tendency for stress reduction $(\mathrm{p}=0.09)$, while there was a tendency for an increase in postassessment in the control group $(p=0.085)$. In conclusion, this study provides insight into the effects of karate training and MBSR training on emotional wellbeing, subjective health, and cognitive function. Although the effect is small overall, the findings indicate that karate training and MBSR are acceptable interventions among the elderly.

\section{Methodological Assessment Results}

Research on the implementation of mindfulness-based stress reduction (MBSR) therapy on psychological well-being in the elderly with depression has proven to be able to cope with stress, depression, anxiety in the elderly and can be applied because it is easy to do and requires no cost. Aside from depression, mindfulness-based stress reduction (MBSR) therapy can also make the elderly feel comfortable being noticed because there are friends to talk to and interact with.

\section{DISCUSSION}

Based on the journal explained in the previous chapter, it was found that the outcome measured in this study was an intervention / therapy of mindfulness-based stress reduction (MBSR) on psychological well-being in the elderly. Mindfulness-based stress reduction (MBSR) therapy can be used as a safe and dangerousless method as an adjunct therapy in addition to pharmacotherapy. Utilizing mindfulness-based stress reduction (MBSR) therapy on psychological well-being in the elderly with depression. The results of this study are recommended to be used as further development of research in this field and to prepare clinical guidelines for using therapy in the social care center of Werdha.

With the conclusion of the exclusion criteria: elderly aged between 60-85 years, elderly with cognitive function problems and emotional well-being issues such as biopsychotic stress to depression, willing to intervene, when to intervene, elderly in good mood / healthy mood and healthy physical condition . exclusion criteria: psychiatric conditions especially major depressive disorders, terminal diseases such as cancer, neurological conditions such as epilepsy and / or parkinsonism, vision and hearing loss, the program consists of four meetings with each meeting consisting of two sessions, each session lasting for 65-75 minutes . Mindfulness techniques used are breath meditation, walking, detection and bodily sensations, releasing desires, SOBER and love, daily activities and evaluation. As for the mindfulness-based stress reduction (MBSR) therapy guide, it is recommended to be with nurses or psychology.

\section{CONCLUSION}

It is hoped that the nurse profession can facilitate the provision of mindfulness-based stress reduction (MBSR) therapy on psychological well-being in the elderly with depression. 


\section{Journal Of Nursing Practice}

http://thejnp.org

ISSN: 2614-3488 (print); 2614-3496 (online)

Vol.4 No.1. October 2020. Page.8-12

So that in addition to pharmacotherapy, the provision of mindfulness-based stress reduction (MBSR) therapy to psychological well-being in the elderly with depression.

\section{REFERENCES}

Autumn M. galleos, Michael hoerger, Nancy L. Talbot, et al. (2015). Emotional Benefits Of Mindfulness Based Stress Reduction In Older Adults: The Moderating Roles Of Age And Depressive Symptom Severity. Journal Of Aging \& Mental Health. Center for Mnd-Body Research, Departement of Psychiatry, University of Rochester Medical Center, Rochester, United State.

Azizah, L. M. (2011). Keperawatan Lanjut Usia. Yogyakarta: Graha Ilmu.

Bazarko, D., Cate, R. A., Azocar, F., \& Kreitzer, M. J. (2013). The Impact Of An Innovation Mindfulness-Based Stress Reduction Program On The Health And Well-Being Of Nursing Employed In A Corporate Setting. Journal of Workplace Behavioral Health.

Bogels, S. M., Hellemans, J., Deursen, S., Romer, M., \& Van der Meulen, R. (2014). Mindful Parenting In Mental Health Care: Effect On Parental And Child Psychopatology, Parental Stress, Parenting, Coparenting And Marital Functioning. Springer Journal of Mindfullness.

Brown, L. K., Weinstein, N., \& Creswell, J. D. (2012). Trait Mindfulness Modulates Neuroendocrine And Affective Responses To Social Evaluative Threat. Psychoneuroendocrinology.

Chen, Y., Yang, X., Wang, L., \& Zhang, X. (2013). A Randomized Controlled Trial Of The Effect Of Brief Mindfulness Meditation On Anxiety Symtoms And Systolic Blood Pressure In Chinese Nursing Students. Nurse Education Today.

Chielsa, A., \& Malinowski, P. (2011). Mindfulness-Based Approaches: Are They All The Same. Journal of Clinical Psychology.

Coatsworth, D., Duncan, L. G., Greenberg, M. T., \& Nix, R. I. (2010). Changing Parent's Mindfulness, Child Management Skills And Relationship Quality With Their Youth: Results From A Randomized Pilot Intervention Trial. Journal Child Family.

Corhorn, C., \& Millicic, N. (2016). Mindfulness And Parenting: A Correlational Study Of Nonmediating Mothers Of Preschool Children. Journal of Child Family.

Data Sensus. Statistik Kesejahteraan Rakyat 2019. Badan Pusat Statistik Republik Indonesia.

Davis, D., \& Hayes, J. A. (2009). Chlinical Handbook of Mindfulness. New York: Springer Science Business Media.

Destiningrum, D. R. (2014). Kesejahteraan Psikologis Lansia Janda/Duda Ditinjau Dari Persepsi Terhadap Dukungan Sosial Gender. Journal Psikologi Undip.

Fachrudin, D., \& Ul Hasanat, N. (2016). Program mindfulness untuk meningkatkan kesejahteraan subjektif perawat. Dalam E. Erawan, A. M. Sumargi, \& N. Effendi (Eds.), Proceeding seminar nasional positive psychology 2016 (hh. 372-381). Fakultas Psikologi Universitas Katolik Widya Mandala Surabaya.

Fortney, L., Luchterhand, C., Zakletskaia, L., Zgierska, A., \& Rakel, D. (2013). Abbreviated Mindfulness Intervention For Job Statisfaction, Quality Of Life, And Compassion In Primary Care Clinicians: A Pilot Study. Annals of Family Medicine.

Garcia-Banda, G., \& Martin-Asuero, A. (2010). The Mindfulness-Based Stress Reduction Program (MBSR) Reduce Stress-Related Psychological Distress In Healthcare Professionals. The Spanish Journal Of Psychology.

Germer, C. K., Siegel, R. D., \& Fulton, P. R. (2005). Mindfulness And Psychotherapy. New York: The Guilford Press. 


\section{Journal Of Nursing Practice}

http://thejnp.org

ISSN: 2614-3488 (print); 2614-3496 (online)

Vol.4 No.1. October 2020. Page.8-12

Grossman, P., \& Van Dam, N. T. (2011). Mindfulness, by any other name...: Trails and tribulations of sati in westerm psychology and science. Contemporary Buddhism, 12(1), 219-239, doi:10.1080/14639947.2011.5648.41.

Hawari. (2007). Sejahtera Di Usia Senja Dimensi Psikoreligi Pada Lanjut Usia. Jakarta: Balai Penerbit UI.

Hurlock, E. (2004). Psikologi Perkembangan. Jakarta: Erlangga.

Hurloc, E. (2008). Psikologi Perkembangan: Suatu Pendekatan Sepanjang Rentan Kehidupan. Jakarta: Erlangga.

Hurloc, E. (2008). Psikologi Perkembangan: Suatu Pendekatan Sepanjang Rentan. Kehidupan. Jakarta: Erlangga.

Indriana, Y., Desiningrum, D.R., \& Kristiana, I. F. (2011). Religiositas, Keberadaaan Pasangan Dan Kesejahteraan Sosial (Social Well Being) Pada Lansia Binaan PMI Cabang Semarang. Jurnal Psikologi Universitas Diponegoro.

Jasmarizal, Sastra, L., \& Yunita, D. (2011). Pengaruh Terapi Musik Klasik (Mozart) Terhadap Penurunan Tekanan Darah Sistolik Pada Lansia Dengan Hipertensi Di Wilayah Kerja Puskesmas Air Dingin Kecamatan Koto Tengah Padang Tahun 2011. Jurnal Mercubaktijaya

Jia-xu Zhang, Xiao-hui Liu, Xin-hui Xie, et al. (2015). dengan judul Mindfulness Based Stress Reduction For Chronic Insomnia in Adults Older Than 75 Years. Journal Mindfulness-Based Stress Reduction.

Kabat-Zinn, J. (1990). Full Catasthrope Living: Using the Wisdom of Your Body and Mind to Face Stress, Pain and Illness. New York: Bantam Dell.

Kementrian Kesehatan Republik Indonesia. Analisis Lansia di Indonesia. Jakarta: Pusat Data dan Informasi Kemenkes RI: 2017.

Keng, S. L., Smoski, M. J., \& Robins, C. J. (2011). Effects Of Mindfulness On Psychological Health: A Review Of Emoirical Studies. Clinical Psychology Review.

Khotimah. (2011). Pengaruh Rendam Air Hangat Dalam Meningkatkan Kualitas Tidur Lansia. Skripsi. PSIK. Universitas Pesantren Tinggi Darul Ulum. Jombang.

Kinasih., \& Sukma, A. (2010). Pelatihan Mindfulness untuk meningkatkan kesejahteraan psikologi pada remaja diabel fisik. Universitas Gadjah Mada. Indonesia.

Lu, L. (2010). Leisure And Depression In Midlife: A Taiwanese Nasional Survey Of MiddleAged Adult. Journal Of Health Psychology.

Mace, C. (2008). Minfulness and mental health: Theraphy, Theory, and Science. New York: Routledge.

Maja o connor, Jacob piet, Esben hougaard, et al. (2015). dengan judul The Effects of Mindfulness Based Cognitive Therapy on Depressive Symptoms in Eldery Bercaved People with Loss-Related Distress. Journal Mindfulness New York.

Maryam, SR, dkk. (2011). Mengenal Lanjut Usia Dan Perawatannya. Jakarta: Salemba Medika.

Nevid, J. S., Rathus, S. A., \& Greene, B. (2005). Psikologi Abnormal Jilid Dua. Jakarta: Erlangga.

Newman, B., \& Newman, P. (2006). Developmental Through Life: A Psycosocial Approach. Belmont: Thamson Wadsworth Learning.

Nurhidayah, S., \& Agustini, R. (2012). Kebahagiaan Lansia Ditinjau Dari Dukungan Sosial Dan Spiritualitas. Journal Soul.

Petra Jansen, Katharina Dahmen Zimmer, Brigitte M, et al. (2016). dengan judul Minfulness Training on Emotional Well Being and Cognitive Performance in Later Life. Petra Jansen, Departement of Psychology, Education and Sport Science. University of Regensburg, Germany. 


\section{Journal Of Nursing Practice}

Piyance Klainin-Yobas, Yanika Kowitlawakul, Violeta Lopez, et al. (2019). dengan judul The Effect of Mindfulness and Health Education Program on the Emotional State and Cognitive Function of Elderly Individuals with Mild Cognitive Impairment. Journal Clinical Neuroscience.

Pratiwi, D. E. (2013). Pengaruh Senam Lansia Terhadap Tingkat Stress Pada Lansia. Skripsi. Poltekkes Surakarta.

Roeser, R. W., Skinner, E., Beers, J., \& Patricia, A. J., (2012). Mindfulness Training And Teacher's Professional Development: An Emerging Area Of Research And Practice. Child Development Perspectives.

Santrock, J. (2002). Life-Span Development $\left(6^{\text {th }}\right.$-ed). New York: Brown and Benchmark Publisher.

Syukra, A. (2012). Hubungan Antara Religiusitas Dengan Kejadian Depresi Pada Lansia Di Panti Sosial Tresna Werdha (PSTW) Sabia Nan Aluih Sicincin Kabupaten Padang Pariaman. Universitas Andalas. Indonesia.

White, L. (2013). Mindfulness in Nursing: An Evolutionary Concept Analysis. Journal Advanced Nursing.

World Health Organization (WHO). Depression. Depression And Other Common Mental Disorders. Geneva: WHO; 2017.

World Population Prospect: 2015. New York: United Nations DESA.

Zulfiana, U. (2014). Meningkatkan Kebahagiaan Lansia di Panti Werda Melalui Psikoterapi Positif alam Kelompok. Jurnal Sains dan Praktik Psikologi. 